\title{
A Study on the Parallel Model of Teaching and Scientific Research of Young Teachers in Colleges and Universities
}

\author{
Yanhua Zhou \\ The Normal School of Beihua University, Jilin City PR China \\ zyqiao2015@163.com
}

\begin{abstract}
Keywords: Young teachers in colleges and universities; Teaching and research; teaching quality; Scientific research ability; Two track parallel mode
\end{abstract}

\begin{abstract}
Young teachers are the driving force for the continuous improvement and development of colleges and universities, young teachers' teaching and research will be directly related to the improvement of the future and destiny of the university. The research on the parallel model of teaching and scientific research is of great significance to improve the teaching and scientific research ability of young teachers. It is also an effective way and method for the construction of teachers in Colleges and universities.
\end{abstract}

\section{Introduction}

Young teachers are the driving force for the continuous improvement and development of colleges and universities, and the improvement of teaching and research will be directly related to the future and destiny of the university. Therefore, it is very important to improve the teaching ability and scientific research ability of young teachers. But in recent years, many colleges and universities to young teachers teaching and research ability training and improve awareness. Some only pay attention to the improvement of scientific research and neglect of teaching, some teaching and scientific research. Many educators have done a lot of work in this field. In 2010(see [1]), Wang Jin, Zhou Guoquan study "how to deal with the relationship between scientific research and teaching in Colleges and universities". In 2000(see [2]), Yang Chunhong, Zhang Shengchun analysis and explore the curriculum system of mathematics major in Normal University, and Sun Qilong, Yu Ping wrote up "On the causes and Countermeasures of College Young Teachers' Job Burnout", Li Jianxuan, Liu Qingnan thought on the optimization management of key discipline construction in Colleges and Universities in 2004(see [3]), I also made reference to the literature [4]-[10]. In this paper, combined with the training of young teachers in the school of mathematics, this paper discusses how to use the parallel model of teaching and research to improve the teaching and research ability of young teachers.

\section{Main Contents of the Research}

Deep Understanding and Experience of Teaching and Scientific Research two Track Parallel Mode. First, grasping the basic ideas and methods of teaching and scientific research two track parallel mode (hereafter referred to as "model"). The so-called dual mode of teaching and scientific research, refers to the improvement of teaching and research to the same line, in unison. In dealing with the relationship between them, the two should be taken into account, can not despise any party.

Second. Fully understand the consistency between teaching and scientific research. In the process of improving the teaching ability of young teachers, we must strengthen the scientific research ability. Stanford University professor Caspar think: seriously engaged in scientific research of teachers can be more profound understanding of scientific laws, grasp the essence of the subject, and then better knowledge; moreover, scientific research experience of the teachers to compare naturally, imperceptibly to the students practical and creative spirit of the infection in the teaching, so that students get great spiritual power, and help the students to learn the way to go, so as to realize the mutual improvement of teaching and scientific research. 
Third. The study of highly valued models. The success of young teachers in Colleges and universities is the key to the development of education and the prosperity of the country. To do a good job in the construction of young teachers is the most important work in Colleges and universities. Practice has proved that the double track mode of teaching and scientific research is an effective way to improve young teachers.

The Significance of the Model Research. First of all, the research of the model provides a practical and powerful help for the cultivation and improvement of young teachers' teaching and scientific research. Teaching and scientific research are the two main lines of young teachers in Colleges and universities, and are the main driving force for the professional development of young teachers. Experience and facts of the development of first-class universities at home and abroad tell us that teaching and research must be carried out with both hands. And the research of the model fully embodies this idea. Therefore, through the study of the mode, teaching and scientific research as a whole, to build a college education environment.

Secondly, the research of the model will greatly promote the development of the discipline construction and personnel training. Young teachers are the main force of teaching and research in Colleges and universities, teaching is the foundation of the school, scientific research is a strong school road, especially for our school like this comprehensive university, young teachers on the development of teaching and scientific research plays an important role. Through the research of the young teachers' teaching and scientific research mode, not only has the important practical significance to do the work of the current college and even the school, but also has a profound influence on the development of the whole education in our country.

Thirdly, the research of the model greatly promotes the development of professional knowledge. The implementation of this model not only helps the young teachers' active teaching and research, and focus on a large number of scientific data model implementation needs are gradually learning, which can greatly promote the quality of teaching and scientific research of the young teachers to improve.

Approaches and Strategies for Implementation. First, actively mobilize, strengthen organizational leadership. School leaders at the beginning of each semester during the planning and layout of the task, alone to the hospital and young teachers' mobilization, asking them to set up the teaching and scientific research consciousness, at the end of the semester were also mobilized, hope the young teachers to use vacation time to enrich their own scientific research level of business.

Second, effective use of professional team and research platform. On the one hand, the hospital leadership requirements of young teachers with their professional direction, choose their own scientific research platform, at the end of the semester or the beginning of the semester arrangement of scientific research platform for academic research, so that each group can have academic plan, step by step to discuss the current situation of the development and the future direction of the research and professional. On the other hand, we should guide the young teachers to combine their professional direction, select the professional team, and strengthen the research of discipline. Actively organize the young teachers of the transverse and longitudinal study of the subject content, such as for young teachers to participate in national, provincial and university level excellent courses and excellent courses of the declaration and the preparatory work, the young teachers become the subject of backbone or leader as soon as possible, to form a good teaching team.

Third, actively guide young teachers to further study and in-depth study. To encourage young teachers to pursue doctoral and postdoctoral studies. At the same time, during every period for doctoral classes, report learning experience, both research and teaching ability, the teaching and research of "walking on two legs", let the young teachers continue to make progress in teaching and teaching methods.

Fourth, improve the mentoring system, give full play to the role of teachers and the Department of. On the one hand, young teachers and teachers of twinning, teaching and research with each class, class evaluation, teaching methods, writing and frontier issues of research, improve the level of their own business as soon as possible; on the other hand, focus on the improvement of young teachers' teaching and scientific research and training for the professional direction and characteristics of the 
young teachers. The organization of young teachers to carry out a series of teaching and research activities, do the demonstration lesson demonstration class, open class, were analyzed and summarized through the introduction of incentives for various types of courses above, improve the enthusiasm of young teachers. At the same time to carry out a series of scientific lectures, academic reports, etc., to enhance the young teachers' teaching and scientific research literacy, improve the enthusiasm of young teachers research.

Fifth, organize the teaching and research time carefully. On the one hand, it is the time of teaching activities, including lectures, evaluation of the class, open class, etc. on the one hand, research activities, including research seminars, research reports, academic reports, etc.. Through the research on the model, not only to help the teachers to form professional ideal consciousness in the education teaching practice, improve professional skills, but also make the young teachers constantly cultivating scientific spirit in scientific research, the formation of innovation consciousness, advocating scientific research with good quality.

\section{Summary}

After several years of research, young teachers have made great progress in teaching and scientific research. Whether it is scientific research, or teaching has been significantly improved, the specific situation is as follows: Table 1 and table 2 .

Table 1 Teaching and scientific research of young teachers before the implementation mode

\begin{tabular}{|l|l|l|l|l|}
\hline teacher age & $\begin{array}{l}\text { Above } \\
\text { years old }\end{array}$ & $\begin{array}{l}\text { Age between 35-45 } \\
\text { years old }\end{array}$ & $\begin{array}{l}\text { young people under } \\
35 \text { years of age }\end{array}$ & $\begin{array}{l}\text { Ratio of young } \\
\text { people }\end{array}$ \\
\hline number & 16 & 19 & 35 & $50.0 \%$ \\
\hline $\begin{array}{l}\text { publish an } \\
\text { article }\end{array}$ & 4 & 6 & 6 & $37.5 \%$ \\
\hline project & 2 & 3 & 1 & $16.7 \%$ \\
\hline $\begin{array}{l}\text { Excellent } \\
\text { course }\end{array}$ & 2 & 5 & 2 & $22.2 \%$ \\
\hline
\end{tabular}

As can be seen from table 1, although the number of young teachers, but in the number of published articles, and the number of applications for the project does not dominate, and the number of people who get excellent class is less pitiful.

Table 2 Teaching and scientific research of young teachers after the implementation mode

\begin{tabular}{|l|l|l|l|l|}
\hline teacher age & $\begin{array}{l}\text { Above } \\
\text { years old }\end{array}$ & $\begin{array}{l}\text { Age between 35-45 } \\
\text { years old }\end{array}$ & $\begin{array}{l}\text { young people under } \\
35 \text { years of age }\end{array}$ & $\begin{array}{l}\text { Ratio of young } \\
\text { people }\end{array}$ \\
\hline number & 14 & 20 & 36 & $51.4 \%$ \\
\hline $\begin{array}{l}\text { publish an } \\
\text { article }\end{array}$ & 4 & 9 & 20 & $60.6 .5 \%$ \\
\hline project & 2 & 6 & 6 & $42.8 \%$ \\
\hline $\begin{array}{l}\text { Excellent } \\
\text { course }\end{array}$ & 1 & 3 & 6 & $60.0 \%$ \\
\hline
\end{tabular}

As can be seen from table 2, the number of young teachers increased by more than one person, but in the number of published articles and the number of outstanding class was significantly dominant, but also in the project application is not backward.

In short, the implementation of the parallel mode of teaching and research is very important to the healthy development of young teachers in Colleges and universities. In order to improve the comprehensive quality of young teachers, we must make full use of this model to ensure the continuous improvement of the overall strength of colleges and universities, and train more and better talents for the country. 


\section{References}

[1] Wang Jin, Zhou Guoquan. How to deal with the relationship between scientific research and teaching in Colleges and universities. Century Bridge. 13 (2010) 96-97.

[2] Sun Qilong, Yu Ping. On the causes and Countermeasures of College Young Teachers' Job Burnout, Journal of Jilin Normal University ( Humanities \& Social Science Edition ). 1 (2000) 101-102.

[3] Li Jianxuan, Liu Qingnan. Thoughts on the optimization management of key discipline construction in Colleges and Universities. Journal of Jiangxi Finance College. 4 (2004) 50-52.

[4] Xu Ling. Some thoughts on strengthening the construction of discipline echelon in Colleges and Universities. Journal of Changchun University of Technology. 28 (2007) 74-75.

[5] Gao Yunzhu. Double track teaching and research of young university teachers in the parallel mode. Education in Jilin. 08 (2012) 6.

[6] Yin Min, Chen Mankun, Shi Biming. On the construction of innovative teachers in Colleges and Universities. China Electric Power Education. 9 (2010) 24-25.

[7] Yang Chunhong, Zhang Shengchun. Analysis and exploration of the curriculum system of mathematics major in Normal University. Journal of mathematical education. 2 (2000) 7-8.

[8] Yan Feng, Liu Yanhui. Discussion on the construction and management of teaching staff in Colleges and universities. Journal of Huizhou University (SOCIAL SCIENCE EDITION). 5 (2011) 99-102.

[9] Xu Qingyun. Reflections on improving the quality of higher education in the stage of popularization of higher education. Science and Technology Innovation Herald. 21(2011) 175-176.

[10]Chen Xizhang. The construction of college teachers should seize the opportunity and meet the challenge. Beijing Higher Education. 1-2(1999) 54-55. 